\title{
Toward a Marxian anthropology? Bare, abstract, mobile, global
}

\author{
Nicholas De Genova ${ }^{1}$
}

Published online: 8 April 2016

(C) The Author(s) 2016. This article is published with open access at Springerlink.com

\begin{abstract}
Anthropology has conventionally taken as some of its most cherished foundational categories the precise opposites of the key concepts that animate this inquiry: rather than "bare life," anthropology has tended always to emphasize the fullness and complexity of social and political life; instead of labor in the abstract, which we recognize in its commodified form as "labor-power," anthropology has produced exquisite inventories of concrete laboring activities and the "cultural" content of productive work; against the impermanence and mutability of lives characterized by their mobility, the ethnographic enterprise has been deeply attached to the sedentarist presuppositions of lasting settlement, dwelling, and "community"; and contrary to the task of apprehending space on a global scale, ethnographic study has been overwhelmingly localized and place-bound. Rethinking these elementary premises of the ethnographic endeavor and situating these critical concepts at the center of our epistemological frameworks are crucial theoretical and practical tasks for any meaningful social inquiry today. In this regard, the Marxian theoretical arsenal is simply indispensable. But, in the derisive words of so many disciplinary forebears and overseers, is this properly "anthropological"? The prospective convergence of genuinely critical sociopolitical inquiry with the techniques and insights of anthropology must remain for us the locus of an urgent problem—an open question on an open horizon.
\end{abstract}

Keywords Bare life $\cdot$ Species being $\cdot$ Labor-power $\cdot$ Migration $\cdot$ Marx $\cdot$ Agamben

In memory of Terence Turner (1935-2015), from whom I first learned to read Marx anthropologically.

Nicholas De Genova

n.degenova@gmail.com

1 Department of Geography, King's College London, The Strand, London WC2R 2LS, UK 
Confronted with the protracted global "crisis" of the world capitalist system, it behooves us to recall Walter Benjamin's incisive reminder that "the tradition of the oppressed teaches us that the 'state of emergency' in which we live is not the exception but the rule" (1940 [1968:257]). Under the global regime of capital accumulation as we know it, crisis has truly become a way of life (cf. Klein 2007; Loewenstein 2015; Mirowski 2013). Indeed, there has been a veritable proliferation of "crisis" talk across the full spectrum of contemporary sociopolitical life (see, for example, De Genova and Tazzioli 2016). Yet, Benjamin's ever-prophetic injunction-no matter how often piously cited-seems to go always unheeded. Our interpretive and analytical traditions tend to be stubbornly impervious to the exigencies and urgent mandates of an intractable and unrelenting state of emergency. Benjamin goes on: "Where we perceive a [mere] chain of events, [history] sees one single catastrophe which keeps piling wreckage upon wreckage..." (1940 [1968:257]). Perceiving these developments only serially (as mere events), we witness this singular accumulation of disastrous tragedies and atrocities, and we inherit the perverse and invidious consequences. We live amidst the wreckages and convert them into the predicates of a way of life. Our social science and historiography descriptively document and record the results. But somehow the urgency of the veritable cataclysm seems to elude our tools of thought.

Our strategies and tactics for changing the world command an interpretation that uncompromisingly inhabits with us the state of emergency in which we live, an analysis that never retreats from crisis-as-a-way-of-life and refuses to avert its critical gaze from the abominable wreckage of a world characterized, now as in Marx's time, by "uninterrupted disturbance of all social conditions, everlasting uncertainty and agitation," in which "all that is solid melts into air" (Marx and Engels 1848 [1967:83]). In his closing lines to The Poverty of Philosophy, Marx declares that "the last word of social science" must be "combat or death; bloody struggle or extinction [nothingness]" (1847 [1963:175]). ${ }^{1}$ Still earlier, in his Introduction to the Critique of Hegel's Philosophy of Right, Marx similarly invoked this dire nexus between struggle and science, between combat and critique:

The weapon of criticism certainly cannot replace the criticism of weapons; material force must be overthrown by material force; but theory, too, becomes a material force once it seizes the masses.... once it becomes radical. To be radical is to grasp matters at the root. But for man the root is man himself (1844 [1970:137]).

Thus, we may better appreciate that the irascible young Marx's revolutionary impatience for a practical disposition adequate to a world where emergency is the rule rather than the exception was no less exigent in its demand for a rigorously radical critique, indeed, a theory capable of truly apprehending the human condition itself. This would seem to suggest, in other words, the necessity for an adequately radical anthropology, in the most fundamentally philosophical sense of the word.

\footnotetext{
1 Marx quotes George Sand's novel Jean Žiska, in French; in the accompanying endnote, the unnamed International Publishers editor translates le néant as "extinction," but I include the perhaps more direct translation—-"nothingness"—as a more philosophically suggestive alternate gloss.
} 
Anthropology as an academic discipline, on the other hand, has conventionally taken as some of its most cherished foundational categories the precise opposites of some of the key concepts that animate what might be characterized as a genuinely Marxian "anthropology." In the present inquiry, I am particularly interested in revisiting some classically Marxian categories of analysis-species being, abstract labor/labor-power, the mobility of labor, and an appreciation of the truly global scale and configuration of capitalism - as well as the less obviously Marxian concept of bare life, proposed by Giorgio Agamben. It seems evident that none of these terms has ever fit very well with the conventions of the institutionalized academic discipline of sociocultural anthropology. Rather than "bare" life-a figure of generic, even empty, humanity-anthropology has tended always to emphasize the fullness and complexity of social and political life; instead of labor in the abstract, which we recognize in its commodified form as labor-power, anthropology has produced exquisite inventories of concrete laboring activities and the "cultural" content of productive work; against the impermanence and mutability of lives characterized by their mobility, the ethnographic enterprise has been deeply attached to the sedentarist presuppositions of lasting settlement, dwelling, and "community"; and contrary to the task of apprehending space and social life on a global scale, ethnographic study has been overwhelmingly localized and place-bound. Rethinking these elementary premises of the ethnographic endeavor and situating these critical concepts at the center of our epistemological frameworks, I will argue, are crucial theoretical and practical tasks for any meaningful social inquiry today. In this regard, the Marxian theoretical arsenal is simply indispensable. But as Marx contended, that theory can only become a subversive material force to the extent that it can truly grasp and critically problematize the contemporary human predicament. Or, in other words, our theory will only be genuinely radical to the extent that it is truly "anthropological." Here, of course, I have in mind no sort of narcissistic exercise of morbid disciplinary anthropological self-congratulation. To the contrary, I am rather more inclined to expect that the discipline of anthropology as we know it, like all other forms of disciplinary knowledge, would most likely be incapable of sustaining the shocks and convulsions of this sort of theoretical (and methodological) reckoning. Indeed, it will be incumbent upon us to confront the inevitable demand, as posed in the derisive words of so many of anthropology's disciplinary forebears and overseers: Is this properly "anthropological"? The prospective convergence of genuinely critical (Marxian, dialectical) sociopolitical inquiry with the techniques and insights of anthropology, therefore, must remain for us the locus of an urgent problem-an open question on an open horizon.

Already I have introduced the rather robust proposition that these four conceptual terms-bare life, abstract labor/labor-power, mobility, and global space-are of indispensable interpretive and critical salience for any meaningful social inquiry today. It will therefore be instructive to consider each of these analytic categories in turn. 


\section{Bare life: and the afterlife of species being}

Whereas I have affiliated the four organizing concepts of this essay to what I am designating to be the Marxian theoretical arsenal, some will surely and promptly object that the idea of bare life is plainly not a strictly or properly Marxian category at all. Let us have a closer look.

In its barest distillation, the concept of bare life, as elaborated by Giorgio Agamben (1995), is only apprehensible in contrast to the plenitude of ways in which human beings really live, namely within and through one or another ensemble of social relations. Bare life is, then, a conceptual foil for all the historically specific and socially particular forms in which human ("biological") life is qualified by its inscription within one or another sociopolitical order. That is to say, "bare" or "naked" life may be understood to be what remains when human existence, while yet alive, is nonetheless stripped of all the encumbrances of social location and juridical identity and thus bereft of all the qualifications for properly political inclusion and belonging (cf. 1999/2002). In this respect, bare life is made to resemble some sort of pure animality of the human species. But of course, this is never true of human existence. The human animal is inextricably a social animal, and that sociality is always inherently historically particular. Bare life, therefore, is an impossible figure of the generic species life of the human animal, treated abstractly. Notably, Agamben is prudent about not reifying or essentializing bare life. Thus, bare life remains an "empty" signifier, an "indeterminate concept" $(1995 / 1998: 182) .^{2}$ Put somewhat differently, bare life-for Agamben himself-is a kind of political fiction. But what is crucial here is to appreciate that, in Agamben's account, modern state power requires and conjures into being precisely this fictive human beast, this naked figure of life bereft, as a necessary premise for the authorization of its own sovereignty. If Agamben is correct, then the matter at hand is not to go hunting for convincing exemplars of an "authentic" bare life, but rather to recognize this grotesquely dehumanized, radically denuded figure of our species existence as the defining horizon toward which we are always already unrelentingly driven, albeit unevenly and unequally in each particular instance. If we have the tenacity to posit humanity as a unitary and universal figure of global political significance, and I believe that we must-even if we simultaneously acknowledge that it may indeed be a kind of normative but necessary fiction-then we are compelled to engage the problematic organized around the comparably fictive idea of bare life.

Bare life, according to Agamben, is literally produced by sovereign (state) power: "the production of bare life" is "the fundamental activity of sovereign power." Bare life presents itself, however, as the "originary political element." It is made to appear, in other words, as something elemental, rudimentary, primeval, "essential," indeed, "biological." As a "threshold of articulation between [human life as] nature and [human life as] culture," however, it must be perennially and incessantly banned or expunged from the political and legal order (1995/1998:181).

\footnotetext{
${ }^{2}$ Agamben explains: "For bare life is certainly as indeterminate and impenetrable as [pure Being], and one could say that reason cannot think bare life except... in stupor and astonishment" (1995/1998:182).
} 
Nevertheless, this banishment or abandonment of bare life by sovereign (state) power, which excludes it from all political life and denies it any juridical validity, inescapably implicates it in "a continuous relationship" (183). In a sense, we may understand sovereign power to legitimate itself by means of a kind of rescue operation, recuperating human (properly social) life from this spectral double that resides stubbornly within the physical materiality of the human species, but only phantasmagorically, as a putatively "natural" or "animal" (debased) mode of (human) being. Bare life is for the state a kind of excess that grounds it, the shadowy cipher of a human foundation that must be thoroughly and rigorously domesticated, upon which the edifice of sovereign power may be erected, but only by cannibalizing it. Whatever remains as an excess-bare life-becomes intolerable, and must be banished. Indeed, inasmuch as it is precisely the regimentation of our social relations and identities by state power that radically separates the phantom of our naked (animal) life from the real (social) lives we lead, bare life in Agamben's account perfectly "expresses our subjection to political power" (182). ${ }^{3}$

Accompanying its rapid and diffuse prominence in recent scholarly discourse, the concept of bare life has been rather too presumptively and reductively degraded to a mere figure of abject "exclusion." Agamben's formulation is rather more subtle, however, as it revolves around "the zone of indistinction between outside and inside, exclusion and inclusion" (181). It is precisely the politicization of bare life that Agamben depicts as the defining "threshold" where the relation between the living (human) being and the sociopolitical order gets substantiated, and where sovereign state power therefore presumes to decide upon and inscribe the humanity of living men and women within its normative and juridical order (8). Thus, Agamben posits a frankly predatory relation between sovereign (state) power and bare or naked (human) life, which is founded always upon their mutually constitutive separation (1996/2000:4; cf. 2003/2005:87).

Bare life-as the reification of a notion of human life that could somehow be merely and purely "biological" - is, for Agamben, precisely not a biological given that ontologically precedes sovereign power, as if in a "state of nature." Rather, bare life is precisely a "product of the [biopolitical] machine" (2003/2005:87-88; emphasis added). Bare life, in other words, is for Agamben the degradation and debasement of the species specificity of human life. Bare life is "that naked supposedly common element that is always possible to isolate in each of the numerous forms of life"; against this, Agamben's political radicality resides in positing the prospective horizon of "a life that can never be separated from its form" (1996/2000:3). ${ }^{4}$ Thus, Agamben's analysis of this constitutive separation

\footnotetext{
${ }^{3}$ It is important to note that Agamben's conception of bare life is substantially an elaboration of Walter Benjamin's discussion of mere life in his "Critique of Violence" (1921/1979:151-53), wherein mere life signals the point where "the rule of law over the living ceases" because law-making violence is a "bloody power over mere life" for the sake of nothing but that same violence (151). I am grateful to Nahum Chandler for pressing me on this point. Agamben acknowledges this genealogy in a brief passage (1995/ 1998:65).

${ }^{4}$ Here, again, it is instructive to compare Agamben's sense with that of Benjamin, who elaborates a sense of "mere life" as analogous to the notion of mere "existence" in contradistinction to "life" as "the irreducible, total condition that is 'man'," (1921[1979:152]) and insists, "Man cannot, at any price, be said to coincide with the mere life in him" (153).
} 
between bare life and the sociopolitical order of sovereign power aspires always to problematize and effectively repudiate that same distinction. ${ }^{5}$ Indeed, politically, Agamben instead seeks nothing less than a life "in which it is never possible to isolate something such as naked [or, 'bare'] life," "a life for which what is at stake in its way of living is living itself... in which the single ways, acts, and processes of living are never simply facts but always and above all possibilities of life, always and above all power" (1996/2000:4.; emphases in original). Thus, Agamben's propositions gesture toward "a life of power" (9; emphasis in original) predicated upon an "irrevocable exodus from any sovereignty" (8), an emancipation from the very division of sovereign (state) power and naked ("biological") life. In contrast to the hegemony of the separation between power and (bare) life, he in fact detects a distinctly human mode of life that "no matter how customary, repeated, and socially compulsory... always puts at stake living itself," making human beings "the only beings for whom happiness is always at stake in their living" (4), "beings that cannot be defined by any proper operation - that is, beings of pure potentiality that no identity or vocation can possibly exhaust" (141).

Here, I would contend, we are in the presence of Marx's conception of species being. With recourse to this term, which he adapts from Feuerbach, Marx addresses himself in his Economic and Philosophic Manuscripts of 1844 to the problem of theorizing the species particularity of the human. As Marx notes, "man is not merely a natural being; he is a human natural being. That is to say, he is a being for himself. Therefore, he is a species being..." (1844 [1964:182; emphases in original]). Furthermore, Marx elaborates, "Man is a species being, not only because in practice and in theory he adopts the species as his object (his own as well as those of other things), but... also because he treats himself as the actual, living species; because he treats himself as a universal and therefore a free being" (1844 [1964:112; emphasis in original]). In spite of our manifold differences, therefore, and in whatever terms we may adopt to do so, we universally posit our own human generality-we posit our own specificities always as encompassed by the universal inclusivity of the human species. Perhaps most crucially, we may appreciate Marx's sense of species being when he clarifies it thus: "The whole character of a speciesits species character-is contained in the character of its life activity; and free, conscious activity is man's species character." What exactly constitutes the particular life activity of the human species? "Labor, life-activity, productive life itself... is the life of the species. It is life-engendering life" (113).

Thus, it is our creative capacity and productive power that distinguish a kind of existential vocation of our species. In its generality and open-endedness, this potential is not reducible to any particularity. Or, as Agamben puts it, such an existential predisposition is precisely a "pure potentiality that no identity or vocation can possibly exhaust." Indeed, Marx continues, "it is only because [man] is a species being that he is a conscious being, i.e. that his own life is an object for him" (113). The free (un-compelled and un-predetermined), conscious (purposive)

\footnotetext{
5 This is a crucial point that tends to be lost in more de-politicized readings of Agamben, which are usually restricted to readings of Homo Sacer (1995), a more esoteric text than the one from which this quote is excerpted, which likewise lends itself to a more narrowly Foucauldean interpretation.
} 
life activity by which human beings materially and practically (re)produce the life of the species as such is, then, to recall Agamben's phrase, a continuous putting at stake of living itself, as well as "happiness" or satisfaction as a conscious aim and objective of that living.

What Agamben glosses as the "pure potentiality" that distinguishes human life can be inferred directly from what Marx distinguishes as the specificity of the human, which he designates as species being. And it is in juxtaposition with this figure of the always constitutively incomplete projects of inexhaustible human possibility that Agamben discerns the abject spectral figure of bare life. In this regard, bare life is apprehensible as a negative, inverted foil for species being. Operating as a debased (merely "natural"/"animal") generalization of the life of the human species, bare life nonetheless serves as a kind of universal (species) limit upon the innumerable and heterogeneous particularities orchestrated or imposed by sovereign power in its manifold juridical and normative regimentations of social life. In other words, although it is a negative and empty figure, bare life nevertheless recapitulates a kind of human universality.

We may appreciate Marx's perspective anew if we situate his thoughts on species being in direct relation to his critical reflections on the notion of "human nature," and the relationship between the putative human "essence" and nature. In Thesis Six of his "Theses of Feuerbach," Marx memorably repudiates the notion of "human nature" (which "can be comprehended only as 'genus', as an internal, dumb generality which naturally unites the many individuals"); in contrast, he argues that "the human essence is no abstraction inherent in each single individual. In its reality, it is the ensemble of the social relations" (1846 [1970:122]; emphasis in original). Thus, Marx concisely dismisses altogether the philosophical centerpiece of bourgeois ideology in favor of the proposition that whatsoever might be characterized as "human nature" is radically contingent and refers us always to the materiality and practicality of social relations as they are configured within historically specific social formations, "particular form[s] of society" (Thesis Seven; p. 122). Nonetheless, in the Economic and Philosophic Manuscripts of 1844, Marx addresses the question somewhat differently, and in a manner that is revelatory for our purposes of assessing bare life as a kind of asocial "natural" (or "biological") dimension of the human species. In his critique of the Hegelian dialectic in the last manuscript, Marx is emphatically interested in the question of so-called "human nature" from the standpoint of re-situating the figure of the human within nature. Rejecting the idealist philosophical conceit that treats of the human as "a non-objective, spiritual being" (1844 [1964:178; emphasis in original]), Marx is expressly concerned with the human as a natural (organic, material, objective) being and therefore as "a part of nature" (112). As Marx puts it, the philosophical figure "Man" ought to be understood as nothing other than "human Nature" - Nature in its specifically human form; "real, corporeal man, man with his feet firmly on the solid ground, man exhaling and inhaling all the forces of nature... at bottom he is nature" (180). As an objective and natural living being, the human consequently exists in a constant (metabolic) relation to external (objective) nature: "Man lives on nature-means that nature is his body, with which he must remain in continuous interchange if he is not to die" (112; emphasis in original]). 
In Marx's account, it is precisely through the practical work in which human beings engage with the objective, external world, and therefore materially objectify human creative energies that the species self-consciousness of human life is made possible. "To say that man is a corporeal, living, real, sensuous objective being full of natural vigor is to say that he has real, sensuous objects as the objects of his being or his life" (181). To be an objective being, and necessarily, to therefore be the object of external forces, is also to take the (external) natural world as the object of one's activity. "The object of labor is... the objectification of man's species life: for he duplicates himself... in reality, and therefore he contemplates himself in a world he has created." The objective realization of human productive activity therefore manifests "species life" as "[man's] real objectivity as a member of the species" (114; emphases in original). In this way, the concept of species being for Marx is inseparable from an appreciation of the material and practical objectivity of the human within nature and as nature, but nevertheless constantly acting (subjectively) on external nature, in a mutually constitutive process of self-objectification.

For Marx, who rejects what he considers to be Feuerbach's "passive" (or "contemplative") materialism (1846), this relation between the human and external nature manifests itself always as dynamic, purposive, creative (subjective) activity-labor-which is transformative of those external circumstances, and effectively re-makes that same "natural" world itself, such that nature itself has by now been thoroughly and completely humanized. Indeed, Marx suggests that human species being consists in a universality that engages practically in enlarging "the sphere of inorganic nature" which human beings appropriate (not simply as means of subsistence but as the material object of our defining life activity), such that "nature is man's inorganic body" (1844 [1964:112; emphasis in original]). "In creating a world of objects by his practical activity, in his work upon inorganic nature, man proves himself a conscious species being... man reproduces the whole of nature" (113; emphases in original). In this sense, all of social life assumes the form of a "second nature," and in fact encompasses the ostensibly natural world itself. As Marx declares, "nature... taken abstractly, for itself-nature fixed in isolation from man-is nothing for man"(1844 [1964: 191; emphases in original]). And further: "Nature as nature... nature isolated... is nothing... is devoid of sense" (192; emphases in original]). In The German Ideology, Marx and Engels revisit this point, polemically, in opposition to Feuerbach's materialism:

So much is this activity, this unceasing sensuous labor and creation, this production, the basis of the whole sensuous world as it now exists that were it interrupted for only a year, Feuerbach would not only find an enormous change in the natural world, but would very soon find that the whole world of men and his own perceptive faculty, nay his own existence, were missing. Of course, in all of this the priority of external nature [to human consciousness] remains unassailed... but this differentiation has meaning only insofar as man is considered to be distinct from nature. For that matter, nature, the nature that preceded human history, is... nature which no longer exists anywhere... (1846 [1970:63]). 
Thus, "history" - that is, the history of human social life- "is the true natural history of man" (1844 [1970:182]), and that history is but the succession of distinct modes for producing material life, entailing "definite form[s] of activity" and "definite form[s] of expressing... life" (Marx and Engels 1846 [1970:42]).

It ought to be plain by now that something like human nature is, for Marx, utterly malleable and mutable. The human "essence" is no more nor less than its essential sociality, which is itself inseparable from its purposive activity, its multifarious labors. The purported "essence" of humankind emerges therefore as but the historically specific and radically contingent manifestation of different modes of productive activity: "As individuals express their life, so they are. What they are, therefore, coincides with their production, both with what they produce and with how they produce [and]... depends upon the material conditions determining their production" (Marx and Engels 1846 [1970:42; emphases in original]). Productive activity is "the real basis of what the philosophers have conceived as 'substance' and "essence of man'." In an idealist conception of history that denigrates that productive activity, Marx and Engels argue that "the truly historical appears to be separated from ordinary life": "the relation of man to nature is excluded from history and hence the antithesis of nature and history is created" (1846 [1970:59]). Marx reconfirms this standpoint in Volume One of Capital:

$[\mathrm{M}] \mathrm{an}$, through his own actions, mediates, regulates, and controls the metabolism between himself and nature... as a force of nature... Through this movement, he acts upon external nature and changes it, and in this way simultaneously changes his own nature. He develops the potentialities slumbering within nature, and subjects the play of its forces to his own sovereign power (1867/1976:283; emphasis added). ${ }^{6}$

Thus, the sheer productive power and creative capacity of human life, the pure potentiality of our vital forces-which we recognize by means of a sometimes misleading short-circuit under the heading of labor-are for Marx the manifestation of a kind of threshold - to revisit Agamben's phrase, a "threshold of articulation between [human life as] nature and [human life as] culture" (1995/1998:181). ${ }^{7}$ Notably, for Marx, this threshold is constantly being crossed, undergoing the practical purposive activity that mediates "the metabolism" between the human species and nature.

\footnotetext{
${ }^{6}$ For a more expanded consideration of the significance of Marx's explicit positing of a conception of "sovereign power" in this passage, in relation to Agamben, see De Genova (2010).

7 For heuristic purposes here, Marx analyzes labor transhistorically- "independently of any specific social formation" (1867/1976:283), and "in a form in which it is an exclusively human characteristic," which is to say, with an emphatic distinction between the consciously premeditated and purposeful characteristic of human labor and the instinctual work of some other species, such as bees constructing a hive or beavers building dams (283-84). This sense of the inextricability of human species-life from labor, for Marx, only thereafter is further specified in terms of the decisive analytical difference between the labor process in general (i.e. "independently of any specific social formation" [1867/1976:283], "in its simple and abstract elements... [as] a universal condition for the metabolic interaction of man and nature, the everlasting nature-imposed condition of human existence... common to all forms of society" [290]) and the labor process as one of alienation and exploitation, "by which the capitalist consumes labor-power" (291).
} 
What figures for Marx as labor-in its ontological, transhistorical sense-is the practical expression of species being, and it is precisely this that comes to be alienated and estranged within capitalist social relations (1844 [1964:106-19]). Similarly, the "pure potentiality" that is not reducible to any particular operation, identity, or vocation, which Agamben identifies with the specificity of the human, may be understood to be the positivity that comes to be banned by sovereign (state) power as bare life. Thus, bare life is activated as a negative foil for the ever openended universality of the human species, in contradistinction to and unrelenting separation from the plenitude of particular juridically inscribed identities. In effect, when Agamben depicts the separation of social life from the ostensibly "natural"/ "animal"/"biological" life of the human species, he is describing a condition of political-juridical estrangement. Bare life is the figure that operates as a condensation of that relation of distinctly political alienation. It can be taken to be the specifically political complement to Marx's analysis of estranged labor.

Much as we can scarcely comprehend human life within the global regime of capital accumulation without recourse to Marx's account of the alienation of labor, the concept of bare life as the political alienation of human potential and creative power would seem to supply an indispensable counterpart. It invokes, albeit in estranged and debased form, a specter of the universality of human species life. Moreover, Agamben's conception of bare life recalls Hannah Arendt's chilling account of the stateless refugee who emerges as the awful "specimen of an animal species, called man" - a "human being in general... without a citizenship" (1951/ 1968: 302) who enacts and embodies "the abstract nakedness of being human and nothing but human" (297). To paraphrase Benjamin, then, we may say that the tradition of the refugees teaches us that the state of emergency is indeed not the exception but the rule. The expulsion of refugees from the precincts of citizenship into a condition of violent exposure as naked and bereft humanness also reveals the state's originary act of cannibalism, positing bare life only in order to domesticate it. Thus, the resurfacing of the figure of bare life in the spectacle of the refugees' misery instigates repetitive crises for sovereign power that can only be remediated by their re-inscription and subjection within a global juridical and normative order. Bare life, therefore, operates as a flashpoint, an alarm; thus, it is the sort of critical concept that may be adequate to-and necessary for-the tasks posed for a genuinely radical social theory. The abstraction of human life as a bare or naked humanness now refers us directly to the decisive figure in Marx's analysis that entails the abstraction of human labor, and its objectification and commodification as labor-power.

\section{Labor-power, the "third thing": the phantom objectivity of abstract labor}

Alongside all the particularities and qualitative differences of the various types of concrete labor, Marx discerned the operation of a figure of human labor in the abstract. In fact, it would not be exaggeration to argue that the analytical category of abstract labor is the veritable key to unlocking the whole question of value and thus 
provides an absolutely decisive and foundational theoretical feature in Marx's critique of capitalist social relations. For the exchange value of commodities remains incomprehensible as long as each is not commensurable with the next in terms of some shared "common element... a third thing" to which they are reducible (1867 [1976:127]). This requires abstracting from the respective particular (qualitative) use values in favor of something they share that differs only in a purely quantitative way. As Marx explains:

With the disappearance of the useful character of the products of labour, the useful character of the kinds of labour embodied in them also disappears; this in turn entails the disappearance of the different concrete forms of labour. They can no longer be distinguished, but are all together reduced to the same kind of labour, human labour in the abstract.... There is nothing left of them in each case but the same phantom-like objectivity; they are merely congealed quantities of homogenous human labour, i.e. of human labour-power... As crystals of this social substance, which is common to them all, they are values-commodity values (128).

Whereas Marx affiliated concrete (variegated) labor with the use value of the distinct products of that labor, and therefore with the whole heterogeneous panoply of positive, determinate, qualitative specificities - in short, with difference as such, and therefore with the historically specific and socially or "culturally" distinctive aspects of human life that anthropologists tend to prize-it was the systemic requirement for the generic form of abstract labor that elucidated the historically specific but global character of alienation, exploitation, and fetishism under capitalism. Labor-power is the elusive "social substance," the determinate or real abstraction that constitutes "the objectivity of commodities as values" (138), supplying all the multifarious products of diverse human creative capacities and productive powers with an identity and equality, differentiated for the purposes of exchange only in quantitative terms.

Marx's analysis of an effectively universal abstraction of human productive energies within the capital-labor relation invites us to contemplate a central figure in any conceivable anthropology of our global condition-the alienating objectification of human life activity as abstract labor, and its commodification as labor-power. Precisely because abstract labor assumes the form of something generic and homogenized, it can readily tend to fall out of the purview of conventional anthropological inquiry. Precisely because its pervasive pertinence assumes the form of a "phantom objectivity," we may be induced to take for granted its quite objective truth and salience. However, to fall into this familiar trap of disregarding what seems to be ubiquitous and mundane is tantamount in fact to neglecting exactly what ethnographic inquiry has always purportedly sought to reveal-namely the organizing forms of social life that are evident in the quotidian textures of everyday life.

To confront the real determinacy of abstraction in our lived everyday life is to peer into the abyss where we are vacated of all that is particular, corporeal, sensuous, and qualitative. Labor-power, as the ubiquitous and pragmatic reification of the fact of our abstraction, is the sort of critical concept that confronts us with the 
crisis of our creative energies being incessantly but routinely pulverized into a generic shadow, prosaically exchanging our vitality for a debased objecthood and “callous 'cash payment"” (Marx and Engels 1848 [1967:82]). The salience of laborpower - the sheer capacity for work, pure potentiality, now commodified for sale on the market-presents itself in an especially compelling fashion, furthermore, when we confront the problem of human mobility.

\section{Mobility and the "radical chains" of migrant labor}

As the veritable source of all value, it is not unreasonable to say that labor-power is the premier commodity in the global circuitry of capitalist exchange. As capital has made and relentlessly re-made the world in its own image, and according to its chaotic requirements, bursting asunder every apparent barrier in the creation of an ever more unobstructed global arena for profit-making and the continuous reconsolidation of a global division of labor, moreover-necessarily, inevitably, and arguably, above and beyond any other commodity, there has also been a concomitant escalation in the mobility of labor-power. But in a world social order that delegates the expressly political tasks of subordination and coercion to more localized formations of more or less organized violence, the parameters of which are demarcated by "national" borders, the global movement of homogenized, abstract labor is finally embodied in the restless life and death of labor in a rather more "concrete" form-which is to say, actual migrant working men and women. Capital can never extract from labor the abstract (eminently social) substance that is "value" except with recourse to the abstraction of labor-power, which, however, can only be derived from the palpable vital energies of living labor. As an operative, indeed decisive, category of capital accumulation, labor-power never ceases to pertain to real flesh-and-blood working people. The accelerated mobility of laborpower, therefore, is inseparable from the migration of actual human beings. As with the mobility of capital itself, which exudes a pronounced indifference toward the particular forms of the labor process where it invests in favor of a maximization of surplus value, and is in this sense exceedingly versatile, so also with the human mobility of labor. Migrant labor mobility is a supreme instance of flexibility, compelled to regard the particular content of one or another type of work with relative indifference, and to render up its labor-power wherever it may be required. The inclination to surmount any "legal [or other] extra-economic impediments to its freedom of movement" is yet another aspect of this versatility (Marx 1867 [1976: 1013]).

In the mass exodus of the Irish fleeing the potato famine of 1846, Marx recognized what he characterized as "a systematic process" that not only entailed "a new way of spiriting a poor people thousands of miles away from the scene of its misery," but also served, in effect, as "one of the most lucrative branches of [Ireland's] export trade" — exporting the labor-power of its surplus population while also mobilizing the migrants themselves as a source of remittances that not only subsidized those left behind but further fueled migration by financing the travel costs of subsequent generations of migrants (1867 [1976:862]). From the opposite 
vantage point of the USA, Marx discerned with respect to Irish labor migration a concomitant importation- "the importation of paupers" (939). Depicting Ireland's colonial condition in terms of "a government ... maintained only by bayonets and by a state of siege sometimes open and sometimes disguised" (863), Marx also discerned how the "forced immigration of poor Irishmen" into the industrial cities of England had enabled the capitalist class to cultivate "two hostile camps" defined by the "profound antagonism between the Irish proletariat and the English proletariat," whereby "the average English worker hates the Irish worker ... [and] regards him somewhat like the poor whites of the Southern States of North America regard their black slaves" (1870 [1971:254; emphases in original]). ${ }^{8}$ Notably, then, the homogenized abstraction of labor-power can be generated only under the aegis of the social production of real heterogeneity and inequality, such as that which W.E.B. Du Bois famously called "the problem of the color line" (1900:95, para.2; and 104, para.19; cf. 1903), or what Partha Chatterjee has designated as "the rule of colonial difference" (1993), as well as what Carole Pateman identifies as "the sexual contract" (1988), and so on. ${ }^{9}$ Hence, the global class politics of human mobility, which routinely transposes a transnational relation of capital and labor into the ostensibly insular "national" politics of "immigration" and border policing, ever increasingly instigates the consolidation of what Étienne Balibar (among others) has depicted as "a world apartheid," which institutes a "color bar" that now no longer merely separates the so-called "center" from "periphery," or North from South, but effectively runs through all "national" state formations (1993/2002: 82; emphases in original; cf. Nevins 2008; Richmond 1994; Sharma 2006).

To the extent that the predicaments of migrant labor invoke the analogies of slavery and apartheid, it is appropriate that we recall Marx's identification of the incipient proletariat as "a class with radical chains." Here, indeed, was a class bereft of property, with no standing in civil society, no historical entitlements, and no particular claims, which embodied not a one-sided and self-interested antithesis to modern conditions but rather a complete antithesis to the very premises of capitalism and the modern state. Thus, here was a class that was not an estate with a positive station within the social order, but rather one that was constituted only negatively, as an abject and "foreign" but inextricable presence, inherently corrosive and always potentially subversive. This class alone revealed "a universal character" and thus could invoke "only a human title" (1844 [1970:141]). In many respects, then, it is the transnational mobility of migrant labor within the global regime of capital accumulation that exceedingly and exquisitely fulfills this profile (De Genova 2010). Indeed, to the extent that migrant labor commonly confronts territorially defined "national" states with the raw force and vital energies of human life-as labor-power-with no juridical sanction, we may recognize anew the figure of bare life, the negative, abject counterpart to human universality and pure potentiality, which sovereign power can only seek to banish.

\footnotetext{
8 I owe a note of gratitude to Dave Roediger for calling this text to my attention.

9 My thinking in this section in particular has been enriched by my ongoing dialog with Nahum Chandler.
} 
Here, indeed, in the heterogeneous figurations of human mobility on a global scale, we may recognize the pernicious stalking and more or less violent regimentation of our relation as a species to the space of the planet. Above all, in the condition of countless migrant denizens whose mobility is branded as "unauthorized" and "illegal," we may discern anew our very species life in the throes of a permanent crisis, enunciating the phrase that Marx deemed to be "that genius which animates material force into political power": "I am nothing and I should be everything" (1844 [1970:140]). Here, then, we arrive-alongside the incessant proliferation of migrant trajectories - at a global space of mobilities that exceeds and surpasses the epistemological and practical conceits of any nationalism.

\section{Global space: human life and the space of the planet}

It is not sufficiently appreciated that for Marx, capitalism was never apprehensible as a European social formation that merely extended itself outward, from an ostensible center out to its far-flung peripheries. Instead, Marx establishes repeatedly that one must understand capital to have been global from its inception. In one of the most forceful articulations of this perspective, in his discussion of "the so-called primitive accumulation" in Volume One of Capital, Marx declares with a flourish:

The discovery of gold and silver in America, the extirpation, enslavement and entombment in mines of the indigenous population of that continent, the beginnings of the conquest and plunder of India, and the conversion of Africa into a preserve for the commercial hunting of blackskins, are all things which characterize the dawn of the era of capitalist production. These idyllic proceedings are the chief moments of primitive accumulation. Hard on their heels follows the commercial war of the European nations, which has the globe as its battlefield (1867 [1976:915; emphasis added]).

Contrary, therefore, to dominant accounts of the beginnings of modern world history that would more predictably locate the America, India, and Africa at the presumed "peripheries" of an expansive European power in its "age of discovery," and for which the vast regions of the globe that were variously conquered and colonized by Europeans are routinely relegated to a marginal status, Marx's critique identifies slavery, colonialism, and warfare as veritable preconditions for the very possibility of capital accumulation. By implication, then, capitalism and a global sociopolitical order of white supremacy were likewise mutually constitutive. It is only with the consolidation of "the world market [dating] from the sixteenth century" that "the modern history of capital starts to unfold" (247; emphasis added). Indeed, the global space of the capitalist world market actually precedes the vast majority of nation states-by centuries. Hence, we cannot presume to produce any sort of meaningful or valid analysis of the modern world without recourse to the conceptual category of global space as a stringent counterpoint to the dominant geopolitical imagination, which remains imprisoned within the presuppositions of methodological nationalism. This is, of course, not to imply that such a global space 
is in any sense "smooth" or frictionless, nor that nation-state spaces and their ever increasingly militarized borders should be imagined to be somehow of little or no consequence. Rather, it is to affirm that the global space of capital accumulation is precisely what Arendt memorably called a "barbed-wire labyrinth" (1951/ 1968:292), deeply scarred with the furrows and trenches that remain the planetary legacies of colonialism, and convulsively riddled with the heterogeneous proliferation of ever more modulated, always (intrinsically) semipermeable, perforated borders (Balibar 1993/2002; Mezzadra and Neilson 2013; Walters 2006, 2011; cf. Harvey 1975/2001; 2000:53-72). Indeed, "without the world-configuring function they perform," clarifies Balibar, "there would be no borders-or no lasting borders" (1993 [2002:79]).

Apart from the recitation of historical events that confirm the planetary scope of capital, however, it is crucial to see how the generalization of relations of commodity exchange, which generates the conditions of possibility for a veritable world market, establishes an effectively universal social condition of human inter-connection which nonetheless assumes an alienated form. That is, it couples abstract, impersonal, apparently independent, mutually indifferent personal relations with a consummate fact of objective social inter-dependency. Thus, capitalism introduces "a system of general social metabolism, of universal relations, of all-round needs and universal capacities ... for the first time." However, "allround dependence of the producers on one another" is conjoined "with the total isolation of their private interests" (1858 [1973:158]). As Marx explains, furthermore: "Just as the division of labour creates agglomeration, combination, cooperation [etc.]... so does private exchange create world trade, private independence creates complete dependence on the so-called world market" (159). Thus, the universality of "production on the basis of exchange values ... produces not only the alienation of the individual from himself and from others, but also the universality and the comprehensiveness of his relations and capacities" (162). Here, then, we return to the theme of universality with which Marx is centrally concerned in his discussion of human species being. The materiality and objectivity of this global inter-dependence are experienced within capitalism only as private atomization (privation) and estrangement. It is nonetheless the material consequence of the capitalist mode of production and mode of life that the human species achieves a universal inter-connectedness and inter-dependency that is unprecedented, and therefore comes to practically inhabit a truly planetary space. Thus, concealed within the existing mode of estranged labor and alienated life, incubating within "society as it is," Marx contends, we may discern some of the "material conditions ... prerequisite for a classless society" (159).

\section{Coda: toward a Marxian anthropology?}

I suggested at the outset of this essay that the prospective convergence of genuinely critical sociopolitical inquiry with the techniques and insights of anthropology must remain for us the locus of an urgent problem - an open question on an open horizon. I hope to have established that such a horizon can only be adequately configured on 
a planetary scale, in a global space of mobilities, where alienated human labor in the abstract and its practical expression as labor-power manifest nonetheless all the pure potentiality of our collective vital energies, our creative capacities and productive powers-as a species. Whether we may prevail over the sovereign power of the state and capital, and ultimately succeed to inhabit our human universality as something more than mere bare life remains the decisive challenge and the definitive task. This is the state of emergency in which we live. But are these questions truly and properly "anthropological"? Only inasmuch as anthropology may still purport to address itself to the problem of the human as such.

Acknowledgments The larger part of this essay was previously published in CR: The New Centennial Review (Volume 12, Number 3 [2012], pp. 129-52), as "Bare Life, Labor-Power, Mobility, and Global Space: Toward a Marxian Anthropology?" These reflections were first presented to the 110th Annual Meeting of the American Anthropological Association, for the panel "Capitalism and Global Anthropology: Marxism Resurgent" (Montreal, 16 November 2011), organized by Patrick Neveling and Luisa Steur. I am grateful to the organizers for inviting me to participate, thus providing me with the occasion to transpose these thoughts into text. I am also grateful to Patrick for his thoughtful and very generous comments. Portions of this text have also been formulated in vigorous dialog with Nahum Chandler. I am also grateful to Winnie Lem for soliciting my contribution to this 40th anniversary issue of Dialectical Anthropology.

\section{Compliance with ethical standards}

Conflict of interest The author declares that he has no conflict of interest.

Open Access This article is distributed under the terms of the Creative Commons Attribution 4.0 International License (http://creativecommons.org/licenses/by/4.0/), which permits unrestricted use, distribution, and reproduction in any medium, provided you give appropriate credit to the original author(s) and the source, provide a link to the Creative Commons license, and indicate if changes were made.

\section{References}

Agamben, Giorgio. 1995/1998. Homo sacer: Sovereign power and bare life. Stanford, CA: Stanford University Press.

Agamben, Giorgio. 1996/2000. Means without end: Notes on politics. Minneapolis: University of Minnesota Press.

Agamben, Giorgio. 1999/2002. Remnants of Auschwitz: The witness and the archive. New York: Zone Books.

Agamben, Giorgio. 2003/2005. State of exception. Chicago: University of Chicago Press.

Arendt, Hannah. 1951/1968. The origins of totalitarianism. New York: Harvest/Harcourt.

Balibar, Étienne. 1993/2002. "What is a border?” Pp. 75-86 in Politics and the other scene. New York, 2002: Verso.

Benjamin, Walter. 1921[1979]. "Critique of violence." Pp. 132-54 in One-way street, and other writings. London/New York: New Left Books.

Benjamin, Walter. 1940[1968]. "Theses on the philosophy of history." Pp. 253-64 in Illuminations: Essays and reflections. New York: Schocken Books.

Chatterjee, Partha. 1993. The nation and its fragments: Colonial and postcolonial histories. Princeton, NJ: Princeton University Press.

De Genova, Nicholas. 2010. "The deportation regime: Sovereignty, space, and the freedom of movement". Theoretical overview. In The deportation regime: Sovereignty, space, and the freedom 
of movement, ed. Nicholas De Genova, and Nathalie Peutz, 33-65. Durham, NC: Duke University Press.

De Genova, Nicholas, and Martina Tazzioli (eds.). 2016. “Europe/Crisis: New keywords of 'the Crisis' in and of 'Europe'”. Near Futures Online. New York: Zone Books.

Du Bois, W. E. B. 1900. The present outlook for the dark races of mankind. A.M.E. Church Review 17(2(66)): 95-110.

Du Bois, W. E. B. 1903[1982]. The souls of black folk. New York: Signet/Penguin.

Harvey, David. 1975/2001. "The geography of capitalist accumulation: A reconstruction of the Marxian theory." Pp. 237-66 in Spaces of capital: Towards a critical geography. New York: Routledge.

Harvey, David. 2000. Spaces of hope. Berkeley: University of California Press.

Klein, Naomi. 2007. The shock doctrine: The rise of disaster capitalism. New York: Penguin.

Loewenstein, Antony. 2015. Disaster capitalism: Making a killing out of catastrophe. New York, London: Verso.

Marx, Karl. 1844[1964]. Economic and philosophic manuscripts of 1844. New York: International Publishers.

Marx, Karl. 1844[1970]. "Introduction to a contribution to the critique of Hegel's 'Philosophy of right'." Pp. 129-42 in Critique of Hegel's "Philosophy of right". New York: Cambridge University Press.

Marx, Karl. 1846[1970]. "Theses on Feuerbach." Pp. 121-23 in Karl Marx and Friedrich Engels, The German ideology, part one (with selections from parts two and three and supplementary texts). New York: International Publishers.

Marx, Karl 1847[1963] The poverty of philosophy. New York: International Publishers.

Marx, Karl. 1858[1973]. Grundrisse: Foundations of the critique of political economy. New York: Vintage/Random House.

Marx, Karl. 1867[1976]. Capital: A critique of political economy, volume one. New York: Vintage/ Random House.

Marx, Karl. 1870[1971]. "From confidential communication." Pp. 252-55 in Karl Marx and Friedrich Engels, Ireland and the Irish question. Moscow: Progress Publishers.

Marx, Karl and Friedrich Engels. 1846[1970]. The German ideology, part one (with selections from parts two and three and supplementary texts). New York: International Publishers.

Marx, Karl and Friedrich Engels. 1848[1967]. The communist manifesto. New York: Penguin Books.

Mezzadra, Sandro and Brett Neilson. 2013. Border as method, or, the multiplication of labor. Durham, NC: Duke University Press.

Mirowski, Philip. 2013. Never let a serious crisis go to waste: How neoliberalism survived the financial meltdown. New York, London: Verso.

Nevins, Joseph. 2008. Dying to live: A story of U.S. immigration in an age of global apartheid. San Francisco: Open Media/City Lights Books.

Pateman, Carole. 1988. The sexual contract. Stanford, CA: Stanford University Press.

Richmond, Anthony. 1994. Global apartheid: Refugees, racism, and the new world order. Toronto: Oxford University Press.

Sharma, Nandita. 2006. Home economics: Nationalism and the making of "migrant workers" in Canada. Toronto: University of Toronto Press.

Walters, William. 2006. Border/control. European Journal of Social Theory 9(2): 187-203.

Walters, William. 2011. Rezoning the global: Technological zones, technological work and the (Un-) making of biometric borders. In The contested politics of mobility: Borderzones and irregularity, ed. Vicki Squire, 51-73. London, New York: Routledge. 